\title{
THE EFFECT OF MULTICULTURAL APPROACH ON READING AND WRITING FOR ELEMENTARY STUDENT
}

\author{
Nashrullah, Noor Alfulaila \\ PGSD, FKIP. Tadulako University, PGMI, Tarbiyah, UIN Antasari Banjarmasin \\ nashrullah@untad.ac.id, nooralfulaila@uin-antasari.ac.id
}

\begin{abstract}
This study aimed at investigating the effect of multicultural approach on reading comprehension and writing skills of grade $V$ elementary school students in the South of Borneo. This is a quasi experimental research with nonequivalent-groups pretest and postest design. The participants experimental class was student of class VB MI Al-hamid Banjarmasin $(n=38)$ and control class was students of class VA MI Al-Hamid Banjarmasin ( $n=36)$. Using reading comprehension and narrative writing test scores of students, multicultural approach questionnaire, and teaching assignment. This study reveals that multicultural approach affects reading comprehension and writing achievement and also becomes the best predictor of their experience and cultural knowledge, such as develops multiple perspectives, cultural counsciousness, increases intercultural competence, combats racism, sexiesm, prejudice, discrimination, and develops social action skills. Furthermore, multicultural approach has a significant effect and better than conventional teaching on students' reading comprehension skills, and on writing skills are also better than convensional approach of teaching. As conclusion, multicultural approach can be considered as a teaching method in improving students' reading comprehension and writing skills, from producing main idea and topik sentence, also writing non fiction text based on multicultural knowledge, awareness, skills and action. The research findings imply that teachers need to change their teaching model into multicultural approach and identify multicultural material to encourage students to do and bring up reading and writing activities related to tolerance.
\end{abstract}

Keywords: Multicultural approach; reading comprehension skills; writing skills

\section{INTRODUCTION}

The State of Indonesia is a country that has ethnic and cultural diversity spread from Sabang to Merauke, such as Javanese, Madurese, Batak, Bugis, Dayak and Banjar tribes. Each tribe has different advantages from other tribes. In other words, Indonesian society is a multicultural society in which many cultures develop. Cultural diversity in society can be seen as potential and vulnerable to conflict. In other words, strategic steps in creating understanding, tolerance and understanding are important, one of which is through education. The meaning of education according to Bung Karno in a broad sense is the transmission and transformation of knowledge, values and skills that take place inside and outside of school which last a lifetime (Siswoyo, 2013a). Thus, education is an important need for every citizen, especially in the 21 st century.

In 21 st century learning requires every individual to participate and take part in the life of the world. This is realized through mastering three new visions of educational skills in the form of basic literacy, competence, and character quality. Basic literacy that needs to be the axis of education includes: 1) literacy literacy, 2) numeracy literacy, 3) scientific literacy, 4) digital literacy, 5) financial literacy, and 6) cultural and civic literacy (Kemendikbud, 2017: 01). One of the six basic literacies that need to be mastered, especially for elementary school age students, is literacy literacy. Reading and writing is the earliest literacy known in human civilization.

As part of literacy, reading is one of the language skills related to almost all processes of learning. One's good reading ability would help him/her learn other subjects. Through reading, individuals learn new information and are capable to synthesize, evaluate and interpret information for the sake of their subject matter learning.

Reading is the key to learning all science, including everyday information and instructions that have a big impact on life. Reading with full understanding can foster each student's empathy for conditions outside the conditions experienced. The more religious the type of reading, the wider the perspective and make more choices in life. Regarding reading, writing skills are also important to 
develop and have. Reading and writing have a positive correlation with language skills and vocabulary mastery. Words and ideas are acquired through reading, while the output is transmitted through writing.In addition to reading and writing, literacy is a term used to refer to being knowledgeable and well-informed (Diem \& Abdullah, 2020; Livingstone et al., 2005).

Based on these six types of basic literacy, the existence, position, function and role of literacy is fundamental and strategic. This is because literacy does not only underlie the overall meaning of the types of literacy that exist today, but also becomes the main pillar of other types of literacy. Therefore, in the context of GLN, literacy in reading and writing is instilled, accustomed and cultivated in the realm of schools, especially SD and MI. The results of the Program for International Student Assessment (PISA) study state that Indonesia's score has decreased compared to the results in 2015 from 397 to 371 in 2018, while the OECD average score is 487. However, data from 2018 PISA showed that the level of reading skill level of 15-year-old Indonesian students was unsatisfactory (OECD, 2019). It ranked 74 out of 79 countries, with more than half of the students' proficient only at or below level 1 . This rank represents serious problems in reading activity as a device to advance and extend knowledge and skills in other areas.

\section{Multicultural education as a learning approach}

Gollnick \& Chinn (2007) defines multicultural education as an educational strategy that utilizes the various cultural backgrounds of students to develop effective teaching in the classroom and school environment. Six important elements related to multicultural education are culture, diversity, equality, social justice, and democracy. However, cultural diversity and equality are two important elements as a minimum requirement of multicultural education. Banks $(2001,2003)$ also agrees with these last two elements as important minimum requirements of multicultural education. In a similar vein, multiculturalism is the condition when individuals with different backgrounds such as culture, language and belief, stay side by side in the same area and respect each other's Differences (Colombo, 2015).

Gollnick \& Chinn (2007) mentions six basic assumptions why multicultural education needs to be developed in schools, namely: a) cultural differences have strengths and values; b) schools must become models for the delivery of human rights and respect for cultural differences; c) fairness and equality for all in schools must be essential in curriculum design and implementation; d) behaviors and values necessary for the survival of a democratic society can be promoted in schools; e) school institutions can be a place for the development of knowledge, skills, and attitudes - values, behavior and commitment - to help students from diverse groups; f) the collaboration of teachers with families and communities can create an environment that supports multiculturalism. This is in line with James A. Banks (Zamroni, 2010b: 1) "teachers need to be multicultural-able to relate many cultures with the Knowledge, skills, and attitudes to better understanding growing student diversity". Thus, multicultural education is thought to be able to assist teachers in implementing several programs that are able to respond to differences in students (students). This can be done by carrying out all the stages for multicultural educators.

There are steps that educators must take in developing themselves to become effective multicultural educators. The stages of this model were developed by Howe \& Lisi (2014: 53), these four stages are a cyclical process which includes knowledge, awareness, skills, and action. In multicultural education, first, educators must develop an awareness of the bias of reality, prejudice, and discrimination faced by others and themselves. Second, educators must also have knowledge of external perspectives and cultures. Third, the need to develop the skills necessary to teach diverse cultures and learning styles.Finally, the need to develop personal action plans (action) in order to increase one's knowledge, skills and tendencies in diversity, as well as efforts to develop institutional action plans through multicultural education. In this study, the development of a multicultural learning model for elementary and MI students, focused on the stages of knowledge (knowledge), awareness and skills and simple action. This is because at the stage of development of elementary school age students who are new to the level of knowing the concept.

Multicultural education is needed as an approach to advance education as a whole and comprehensively. Apart from the principle of flexibility, literature / books as a source of student learning are also important. Multicultural literature is a tool to support the development of cultural awareness and appreciation. This is in line with the results of the previous studies done by Futrell, 
Gomez, \& Bedden (2003) and Gorski (2006) that having wellrounded multicultural knowledge is vital for student teachers' attentiveness, preparedness, and mindsets concerning students of diverse backgrounds they will eventually teach. Multicultural literature includes six types of literature, and each type of group offers a different perspective and contribution to life. Six types of multicultural literature, namely: 1) folktales and other traditional stories, 2) Historical Fiction, 3) Contemporary realistic fiction, 4) Contemporary stories, depicting the experiences of people living with different cultures, 5)Biographies, books that describe the contributions made by different groups of people from different cultures, and 6) Poetry (Tompkins \& Hoskisson, 1995: 534-535). Several collections of poetry and songs written by people from many different cultural groups such as Informational book. Books that provide information about various cultures, including information on religious holidays, language, cuisine, and art, including information about the country where the culture originates.

Each learning plan has one, two, or more multicultural learning objectives, this can be seen through a check list prepared by the educator, Bennett (Howe \& Lisi, 2014: 203-204)

Multicultural Goal (s) (check one or more)

- Developing multiple historical perspectives

- Developing cultural consciousness

- Increasing interculturalcompetence

- Combating racism, prejudice, and discrimination

- Developing awareness of the state of the planet and global dynamics

- Developing social action skills

This is in line with Yilmaz's (2016) study explored teacher candidates' perceptions of multicultural education and found that their positive attitudes toward ME help shape their understanding of diversity and respect for individual differences. Studying the administration of ME in a school in Medan, Indonesia, Purba et al. (2019) found that multicultural education program has improved students' tolerance of religious and ethnic differences.

\section{Indonesian language for elementary students}

Language cannot be separated from human life as social creatures. In general, language as expressed by Boeree (2010: 117) is defined as a system of symbols with several levels of organization (at least there are phonetics, syntax, and semantics). Indonesian is the language that unifies the nation which must be mastered by every Indonesian citizen.

Naturally, Indonesian language learning is directed at improving the ability of students to communicate in spoken and written Indonesian, as well as fostering appreciation for Indonesian literary works and intellectual works of the nation itself (Gipayana, 2008). Learning Indonesian in elementary school has an important value, because at this level of education that the first time teaching Indonesian is implemented in a planned and directed manner. The general objectives of learning Indonesian in SD / MI (in Puskur Balitbang Depdiknas 2002) are : 1) Students appreciate and pride themselves on Indonesian as the language of unity and the language of the country; 2) Students understand Indonesian in terms of form, meaning, and function as well as its proper and creative use for various purposes, needs and circumstances, 3) Students have the ability to use Indonesian to improve intellectual abilities, emotional maturity and social maturity, 4) Students have discipline in thinking and language, 5) Students are able to enjoy and take advantage of literary works to develop their personality, broaden their horizons in life and increase their knowledge and language skills, 6) Students appreciate and pride themselves on Indonesian literature as a cultural and intellectual treasure.

The scope of Indonesian language learning includes components of language skills or literacy skills which include the following aspects: (1) listening, (2) speaking, (3) reading, and (4) writing (Kemendikbud, 2006: 318). First, in the listening aspect, the material is related to listening to news, instructions, announcements, orders, sounds or voices, language sounds, songs, tapes, messages, explanations, reports, lectures, speeches, speakers, dialogue or conversations, announcements and orders heard by responding appropriately and appreciating and expressing literature through listening to literary results in the form of fairy tales, children's stories, folk tales, animal stories, children's poetry, song lyrics, rhymes and watching children's dramas.Second, in the aspect of speaking related to the material: expressing ideas and feelings; delivering remarks, dialogues, messages, experiences, a process, telling oneself, friends, family, society, plant objects, animals, experiences, single pictures, serial 
pictures, daily activities, events, favorite characters, and likes / dislikes, hobbies, regulations, rules, instructions and reports as well as appreciating and expressing literature through verbalizing literary products in the form of fairy tales, children's stories, folk tales, animal stories, children's poetry, song lyrics, rhymes and children's dramas. Third, on the reading aspect related to the material: reading letters, syllables, sentences, paragraphs, various reading texts, floor plans; instructions, rules of conduct, announcements, dictionaries, encyclopedias as well as appreciation and expression of literature through reading literary results in the form of dongenng, children's stories, folk tales, animal stories, children's poetry, song lyrics, rhymes, and children's drama of reading competence, are also directed foster a reading culture. In fact, reading activity is a significant area of an individual's learning (Noor, 2011). It is a basic skill for learning, a key indicator of success in school and in life (AASL, 2007) and is a test component required in national examination in Indonesia (Sunggingwati \& Nguyen, 2013). Fourth, in the aspect of writing related to the material: writing narrative and non-narrative essays in neat and clear writing by showing the objectives and variety of readers, using spelling and punctuation, proper vocabulary using single sentences and compound sentences and appreciating through writing literary results in the form of stories and poetry. Writing competence is also directed at fostering writing habits.

The following is an explanation of the stages of cognitive development of children aged MI or $\mathrm{SD}$, namely the Concrete Operational stage (7-11 years). This stage is marked by extraordinary cognitive growth and is a formative stage in school education, especially for elementary school children or Madrasah Ibtidaiyah. At this stage, the child's language and basic skills mastery develop rapidly. Children begin to show abstract thinking even though it is depicted through characters or actions. Children at this stage also display thoughts that are less egocentric, and their language becomes more and more social. (Schunk, 2012: 333). Thus, SD / MI students can carry out activities that involve objects and can also reason logically, as long as it is applied with specific or concrete examples.

\section{METHOD}

It is very important to improve students' literacy skills in reading and writing through a multicultural approach. This is based on the PISA report which states the low literacy skills of students and the high cases of bullying that occur in schools. The ability to read comprehension is related to the process of identify, recall or literal comprehension, analyze, interpretive, inferential comprehension, judge, critical comprehension, extend and creative comprehension, while writing is related to narrative essays in expressing feelings, thoughts, and information in the form of simple essays. The multicultural approach is concerned with developing multiple historical perspectives. Developing cultural consciousness, increasing intercultural competence, combating racism, prejudice, and discrimination, Developing awareness of the state of the planet and global dynamics, developing social action skills.

\section{Design}

This research is a quantitative research with a Quasi experiment approach. The research design used was the Nonequivalent-Groups Pretest-Postest Design. The population of this study were all students of class V MI Al- Hamid Banjarmasin, totaling 74 students. The sample was taken by using cluster random sampling technique. The research sample was 36 students of class VA as the control class and 38 students of class VB as the experimental class. Techniques and data collection instruments The techniques used in the data collection process were tests. The test is carried out at the time before the treatment is given which is called the pretest and when students finish receiving the treatment called the posttest. The data collection instruments were a reading comprehension skill test and a writing skill test.

\section{Instruments}

To find out the skills of reading comprehension and writing narratives of fifth grade students, the research instrument was used in the form of a multiple choice test. The stages of developing a reading comprehension skill test instrument are as follows: 1) looking at the basic competencies and core competencies of the material related to the theme of being proud of being an Indonesian nation; 2) compile grid questions and indicators of reading comprehension skills; 3 ) Arrange items based on basic competencies and indicators; 4) validation of the instruments that have been made by asking the help of an expert validator, namely Dr. Kastam Syamsi, and practitioner Validators namely Ibu Rahimah Mas'ud, S. Pd; 5) Conducting instrument trials in classes that have received material on the theme of 
being proud of being the Indonesian nation; 6) Estimation of the validity and reliability of research instruments; 7) Revision of research instruments in accordance with suggestions for improvement..

\section{Validity, reliability and procedure}

Validity is divided into two, namely rational validity and empirical validity. In measuring the rational validity of all instruments using expert opinion or experts in their field (expert judgment), while for testing the empirical validity uses a test instrument in the trial class. For the test instrument, reading comprehension skills and narrative writing skills were in the form of multiple choice test questions.

Quoting the opinion of Reynolds, Livingstone \& Wilson (2010, p.91) who stated that "reliability refers to consistency or stability of assessment result". This means that reliability refers to the consistency or consistency of the results of a measurement. using the basic formula Alpha Cronbach formula. The data obtained were analyzed through three stages, namely the data description stage, the analysis prerequisite test stage and the hypothesis testing stage. The data normality test used the Kolmogorov-Smirnov test, the homogeneity test used the Lavene test, and the collinearity test used the Linear Regression Test and the Correlation Test using the SPSS 20 for Windows computer program. This study has two hypotheses. In testing these two hypotheses using the MANOVA test technique. Muijs (2011,p. 187) states that "MANOVA allows us to test hypotheses regarding the effect of one or more independent variables on two or more dependent variables". This means that MANOVA provides an opportunity to test the hypothesis of the influence of one or more independent variables on two or more dependent variables.

\section{RESULTS}

Based on Table 01, it is known that the experimental class on the reading comprehension skill variable obtained a maximum value of 83.00 and a minimum value of 61.00 . The average is 74.06 . In the variable of narrative writing skills, the maximum value is 80.00 and the minimum value is 75.00 with a mean value of 77.27. The pretest result data is presented in Table 01 below.

Table 1. Data Pretest Reading Comprehension and Writing Skills

\begin{tabular}{llcc}
\hline Class & Score & \multicolumn{2}{c}{ Variabel } \\
\hline & & $\begin{array}{c}\text { Reading } \\
\text { Comprehension }\end{array}$ & Writing Skills \\
\hline Eksperiment & Minimum & 61,00 & 75,00 \\
& Maximum & 83,00 & 80,00 \\
& Rerata & 74,06 & 77,27 \\
\hline Control & Minimum & 70,00 & 70,00 \\
& Maximum & 74,00 & 80,00 \\
& Rerata & 71,45 & 72,08 \\
\hline
\end{tabular}

Based on Table 01 also, it can be seen that the control class on the reading comprehension skill variable obtained a maximum value of 74.00 and a minimum value of 70.00 . The average is 71.45 . In the narrative writing skill variable, the maximum value is 80.00 and the minimum value is 70.00 with a mean value of 72.08. The data from the posttest research results are presented in Table 02 below.

Table 2. Posttest Data On Reading Comprehension and Writing Skills

\begin{tabular}{llcc}
\hline Class & Score & \multicolumn{2}{c}{ Variabel } \\
\hline & & $\begin{array}{c}\text { Reading } \\
\text { Comprehension }\end{array}$ & Writing Skills \\
\hline Eksperiment & Minimum & 64,00 & 71,00 \\
& Maximum & 90,00 & 99,00 \\
& Rerata & 78,89 & 87,92 \\
\hline Control & Minimum & 65,00 & 62,00 \\
& Maximum & 87,00 & 86,00 \\
& Rerata & 75,74 & 74,12 \\
\hline
\end{tabular}

Based on Table 02 it is known that the experimental class on the variable reading comprehension skills obtained a maximum value of 90.00 and a minimum value of 64.00 . The average is 78.89. In the variable of narrative writing skills, the maximum value is 99.00 and the minimum value is 71.00 with a 
mean value of 87.92. Based on Table 02 also, it can be seen that the control class on the reading comprehension skill variable obtained a maximum value of 87.00 and a minimum value of 65.00 . The average is 75.74 . In the variable of narrative writing skills, the maximum value is 86.00 and the minimum value is 62.00 with a mean value of 74.12 .

\section{Test Prerequisite Analysis}

Test Prerequisite Analysis includes normality test, homogeneity test and data collinearity test. The population normality test is carried out to determine whether the test result data that has been carried out are normally distributed or not. The normality test was carried out on all data in both the experimental class and the control class. Normality testing uses the Kolmogorov-Smirnov method using the SPSS 20 for Windows program. Table 03 below presents a summary of the results of the normality test in the experimental group and the control group.

Table 3. Summary of Normality Test in The Control and Eksperimental Group

\begin{tabular}{lccccc}
\hline \multicolumn{5}{c}{ Sariabel } & \multicolumn{2}{c}{ Eksperiment } & \multicolumn{2}{c}{ Control } & \multirow{2}{*}{ Status } \\
\cline { 2 - 5 } & Pretest & Posttest & Pretest & Posttest & \\
\hline Reading & 0,875 & 1,194 & 1,28 & 0,737 & Normal \\
Comprehension & & & & & \\
\hline Writing Skills & 0,565 & 0,875 & 0,89 & 1,270 & Normal \\
\hline
\end{tabular}

Based on Table 03, the pretest data normality test reading comprehension for the experimental class and control class obtained a significance value of 0.872 and 1.282, which are greater than the specified alpha value, namely 0.05 . Thus it can be concluded that the pretest value of reading comprehension in both the experimental group and the control group is normally distributed. Likewise, the pretest value of narrative writing where the significance value for the experimental class is 0.565 and the control class is 896 . The acquisition score was higher than the alpha score set at 0.05 , so it could be concluded that the value of writing narration in both the experimental and control groups was normally distributed. Based on Table 03 it is also known that the posttest data on the normality test of reading comprehension for the experimental class and the control class. The post-test data reading comprehension obtained a significance value in the experimental group of 1.194 and 0.737 in the control group, so the acquisition score was greater than the alpha value set at 0.05 . Thus it can be concluded that the posttest scores of reading comprehension in both the experimental group and the control group are normally distributed. Likewise, the post-test score of writing narrative where the significance value obtained for the experimental class was 0.875 and the control class was 1.270 . The acquisition score was higher than the alpha score set at 0.05 , so it could be concluded that the value of writing narration in both the experimental and control groups was normally distributed.

\section{Homogenity Test}

Homogeneity testing was carried out by Lavene's homogeneity method using SPSS 20 for Windows. Homogeneity test is used to find out the data before and after treatment whether it has the same variance or not. More details can be seen in Table 04 below.

Table 4. Summary Of Data Homogeneity Pretest and Posttest

\begin{tabular}{cccc}
\hline Variabel & \multicolumn{2}{c}{ Levenes's Significancy } & Status \\
\cline { 2 - 3 } & Pretest & Posttest & \\
\hline $\begin{array}{c}\text { Reading } \\
\text { Comprehension }\end{array}$ & 0,085 & 0,076 & Homogen \\
\hline Writing Skills & 0,098 & 0,570 & Homogen \\
\hline
\end{tabular}

Based on Table 04, it is known that Lavene's significance value for the reading comprehension. variable before treatment is 0.085 . This score is greater than the assigned alpha value of 0.05 , so it can be concluded that the pretest data reading comprehension in both the experimental group and the control group is homogeneous. Based on Table 04, data for the narrative writing variable were also obtained, before the treatment was with a score of 0.076 and this value was higher than the alpha price set at 0.05 . Thus it can be concluded that the pretest data for narrative writing skills in both the experimental group and the control group are homogeneous. The significance value after treatment is obtained a figure of 0.570 . This value is greater than the specified alpha price of 0.05 , so it can be 
concluded that the post-test data for narrative writing skills in both the experimental group and the control group are homogeneous.

\section{Data Collinearity Test}

The use of the collinearity test is intended to determine the relationship between the two dependent variables in both the experimental class and the control class as a prerequisite for the MANOVA test. Collinearity test is very important to do to see whether the two dependent variables do not have a linear relationship with the independent variable. The criteria used are: 1) if the VIF (variance inflation factor) value is around number 1, it can be said that there is no collinearity problem in the regression model; 2) if the correlation coefficient between the independent variables is less than 0.8 then there is no collinearity problem. Based on the results of the calculation of SPSS 20 for Windows, the VIP value is 1 and the correlation value between the dependent variables is 0.760 . This correlation number is smaller than 0.8 , so it can be concluded that there is no collinearity between the reading comprehension skills and narrative writing skills. Thus the MANOVA test can be continued.

\section{Hypothesis test}

Based on the results of the prerequisite test that has been carried out, it is known that the research data for both the pretest and posttest were normally distributed and the variance between groups was homogeneous. Thus, data analysis can be continued to hypothesis testing.

The first hypothesis test uses the postest value of reading comprehension skills in the experimental clas s and the control class. The purpose of this test is to determine the effect of multicultural-based learning on the dependent variable, namely reading students' understanding. This hypothesis testing technique uses MANOVA assisted by SPSS 20 for Windows. The output results show that the significance value is 0.000 , because the acquisition value is less than the specified alpha price, which is 0.05 , meaning that there is a difference in the average of the experimental class and the control class, so Ho is rejected and Ha is accepted. Thus it can be concluded that there is a significant influence on multicultural-based learning on students' reading comprehension skills. More details can be seen in Table 05 below.

Table 5. Manova Test Results Reading Comprehension of Eksperiment Group and Control Group

\begin{tabular}{cccc}
\hline Variabel & F & df & Sig \\
\hline $\begin{array}{c}\text { Reading } \\
\text { Comprehension }\end{array}$ & 30,55 & 1 & 0,00 \\
\hline
\end{tabular}

The second hypothesis test uses the post-test value of narrative writing skills in the experimental group and the control group. This test aims to determine the effect of multicultural-based learning on the dependent variable, namely writing student narratives. This hypothesis testing technique uses MANOVA assisted by SPSS 20 for Windows. The output results show that the significance value is 0.000 , because the acquisition value is less than the specified alpha price, which is 0.05 , meaning that there is a difference in the average of the experimental class and the control class, so Ho is rejected and $\mathrm{Ha}$ is accepted. Thus it can be concluded that there is a significant influence on multicultural-based learning on students' narrative writing skills. For more details, see Table 06 below.

Table 6. Summary of Manova Test Results Writing Narrative Eksperiment Group and Control Group

\begin{tabular}{cccc}
\hline Variabel & F & df & Sig \\
\hline Writing Skills & 30,39 & 1 & 0,00 \\
\hline
\end{tabular}

\section{DISCUSSION}

The results of this study aimed to see the effect of multicultural-based learning on reading comprehension skills and writing narratives of fifth grade students at MI Al-Hamid Banjarmasin. Description and data analysis are needed in order to draw the right conclusions about the effects of this multicultural-based learning.

\section{The influence of multicultural-based learning on reading comprehension skills}

Based on the value and results of postest data analysis on reading comprehension skills on the theme of being proud of being the Indonesian nation (Theme 5), students who get multicultural-based learning show that overall reading skills are understanding about the theme of being proud of being 
Indonesian with the subject of understanding paragraphs and main ideas, better than the control class who received conventional learning. This is evidenced by the difference in the average final score of the two groups where the experimental group obtained an average postest score of 78.89 while the control group was only 75.74. Based on these results, it has been seen that multicultural-based learning has a better effect than conventional learning on reading comprehension skills with the subject of understanding paragraphs and finding main ideas. Hypothetical test using MANOVA obtained a significance value of 0.000 , this figure is far below the specified alpha, namely 0.05 . Thus it can be concluded that there is a significant effect of multicultural-based learning on students' reading comprehension skills. This in line with Noor research (2019) that multicultural approach provides freedom in expressing ideas and thoughts to encourage students to express their opinions confidently so they can enhance the learning quality. The freedom to express themselves in case of opinions can increase the students' learning motivation, as an important factor in the learning process that reflected in the applicable curriculum.

\section{The influence of multicultural-based learning on writing skills}

Based on the value and results of postest data analysis on narrative writing skills on the theme of being proud of being the Indonesian nation (Theme 5), students who received multicultural-based learning showed that overall narrative writing skills on the theme of Proud to be Indonesian are better than the control class who got learning conventional. This is evidenced by the difference in the average final score of the two groups where the experimental group obtained an average postest score of 77.27 while the control group was only 72.08. Based on these results, it has been seen that multicultural-based learning has a better influence than conventional learning on students' narrative writing skills. Hypothetical test using MANOVA obtained a significance value of 0.000 , this figure is far below the specified alpha, namely 0.05 . Thus it can be concluded that there is a significant influence on multicultural-based learning on students' narrative writing skills.

These findings indicate that multicultural-based learning has a positive or better effect in improving students' narrative writing skills. In multicultural-based learning, students get the opportunity to better understand cultural diversity and the messages contained therein, exchange ideas with group friends and work together in completing assignments given through the LKPD given by the teacher. Baptiste, Jr. (1986) stated that ME affiliates itself with the nature of cultural pluralism. To internalize the concept of ME, teachers need to understand various definitions posited by the researchers in ME field cited earlier (see Banks, 2001a, 2001b; Brent, 1982; Fowers \& Davidov, 2006; Shannon-Baker, 2018; Singh, 1984; Suzuki, 1979; Yilmaz, 2016). Although the formalization of the concept of ME is somewhat less familiar in the Indonesian educational system, by studying the definition provided by the researchers above, it is apparent that the concept of ME is valid for every nation in the world, especially for one that is multiethnic or multicultural like Indonesia, and a mixture of different ethnic groups can easily be found in big cities like Banjarmasin.

The final model also revealed that there is a significant direct path from discourse synthesis strategies to summary writing performance, suggesting that the use of strategies such as selecting the important and relevant ideas from the source texts, organizing them, and building meaningful connections between them significantly predict performance in a reading-to-write task. This is in agreement with past research on the role of discourse synthesis in integrated writing performance (Zhu et al., 2020; Cheong et al., 2019; Plakans \& Gebril, 2013, 2017; Yang, 2014; Yang \& Plakans, 2012; Zhu et al., 2020).

\section{CONCLUSION}

The main conclusion drawn from this study is related to teachers' growth in teaching strategies and multicultural education awareness and sensitivity. There is little evidence for definite answer at thos stage. Multicultural-based learning provides a better and significant effect compared to conventional learning on reading comprehension skills in terms of cognitive abilities of students in Islamic elementary schools. This is evidenced by the sig value. 0.000 is smaller than the assigned alpha value $\alpha=0.05$. The second important conclusion is that Multicultural-based learning provides a better and significant impact than conventional learning on narrative writing skills in terms of making effective sentences. This is evidenced by the sig value. 0.000 is smaller than the assigned alpha value $\alpha=0.05$. 


\section{REFERENCES}

American Association of School Librarians (AASL). (2007). Standard for the 21st century learner. ASL. Accounting education, 13 (sup 1), 25-37. Doi: 10.1080/0963928042000310779

Ahn, S. (2019). Decoding "good language teacher"(GLT) identity of native-English speakers in South Korea. Journal of Language, Identity \& Education, 18(5), 297-310.

Banks, James A. (2003). An introduction to multicultural education. Boston: Allyn and Bacon. --------. (2005). Issues And Perspectives (Fifth Edition). New Jersey: John Wiley \& Sons, Inc.

--------. (2003).Teaching for multicultural literacy, Global citizenship, and social justice.

Baptiste, H. P., Jr. (1986). Multicultural education and urban schools from a sociohistorical perspective: Internalizing multiculturalism. Journal of Educational Equity and Leadership,6, 295 - 312. https://doi.org/10.1177\%2F004208599703200 1007

Banks, J. A. (2001a). Multicultural education: Goals, possibilities and challenges. In C. F. Diaz (Ed.), Multicultural education in the 21st century (pp. 11-22). Addison-Wesley.

Banks, J. A. (2001b). History, characteristics and goals. In J. A. Banks \& C. A. M. Banks (Eds.), Handbook of research on multicultural education (pp. 3-29). Wiley

Beker, G. C. (1994). Planning and organizing for multicultural instruction. (2nd). California: Addison-Elsey Publishing Company.

Benson, P \& Lor, W. (1999). Conceptions of language and language learning. System, 27(4), 459457. Doi:10.1016/s0346-251x(99)00045-7

Brackett, M. A. (2008). Development of the teacher: Interview transcript. 4 researchers. http://www.4researchers.org/articles/transcript/2530

Brent, A. (1982). Multicultural education and relativism: A reply to Phillips-Bell. Journal of Philosophy of Education, 16, 125 - 130. https://doi.org/10.1111/j.1467- 9752.1982.tb00604.x

Brown, H. D. (2007). Prinsip pembelajaran dan pengajaran bahasa. Edisi Kelima. USA: Pearson Education, Inc. Byrne, M., \& Flood, B. (2004). Exploring the conceptions of learning of accounting students.

Campbell, R. L., \& Farrell, R. V. (1985). The identification of competencies for multicultural teacher education. Negro Educational Review, 36, 137 - 44.

CHANG, Ethan. Redacting 'Stock Stories' of Education Inequities: Toward Legitimate Digital Participation. International Journal of Multicultural Education, [S.1.], v. 22, n. 2, p. 163-181, aug. 2020. ISSN 1934-5267. Available at: <https://ijmejournal.org/index.php/ijme/article/view/2409/1377>. Date accessed: 05 jan. 2021. doi:http://dx.doi.org/10.18251/ijme.v22i2.2409

Cheong, C. M., Zhu, X., Li, G. Y., \& Wen, H. (2019). Effects of intertextual processing on L2 integrated writing. Journal of Second Language Writing, 44(March), 63-75. https://doi.org/10.1016/j.jslw.2019.03.004

Colombo, E. (2015). Multiculturalism: An overview of multicultural debates in western societies. Current Sociology Review, 63(6), 800-824. https://doi.org/10.1177/0011392115586802

Delgado, R., \& Stefancic, J. (2001). Critical race theory: An introduction. New York University Press. Delpit, L. (1995). Other people's children: Cultural conflict in the classroom. New Press.

Devianty, Rina. (2017). Peran Bahasa Indonesia Dan Bahasa Daerah Dalam Pendidikan Karakter. Ijtimaiyah: Jurnal Pendidikan dan Ilmu Sosial, 1 (2). pp. 79-101. ISSN 2541-660X

Diem, C. D. \& Abdullah, U. (2020). Promoting multiculturalism: Teachers' English proficiency and multicultural education in Indonesia. Indonesian Journal of Applied Linguistics, 10(1), 46-58. https://doi.org/10.17509/ijal.v10i1.24983

Fowers, B. J., \& Davidov, B. J. (2006). The virtue of multiculturalism: Personal transformation, character, and openness to the other. American Psychologist, 61, 581-594. http://dx.doi.org/10.1037/0003-066X.61.6.581

Futrell, M. H., Gomez, J., \& Bedden, D. (2003). Teaching the children of a new America: The challenge of diversity. Phi Delta Kappan,84(5), 381-385. https://doi.org/10.1177/003172170308400512 Gorski, P. C. (2006). Complicity with conservatism: The depoliticizing of multicultural and intercultural education. Intercultural Education, 17(2), 163-177. https://doi.org/10.1080/14675980600693830

Griffiths, C., \& Cansiz, G. (2015). Language learning strategies: an holistic view. Studies in Second language Learning and Teaching, 5(3), 473-493. Doi:10.14746/ssllt.2015.5.3.7 
Jennings, P. A., \& Greenberg, M. T. (2009). The prosocial classroom: Teacher social and emotional competence in relation to student and classroom outcomes. Review of Educational Research, 79(1), 491-525. https://doi.org/10.1007/s11251-014-9338-1 Kartadinata, Sunaryo, dkk. (2015). Pendidikan Kedamaian. Bandung: PT. Remaja Rosdakarya. Kang, S.-W. (2010). Multicultural education and the rights to education of migrant children in South Korea. Educational Review, 62(3), 287-300.

Kemendikbud. (2013). Kompetensi dasar SD/MI. Jakarta: Kementerian Pendidikan dan Kebudayaan.

----- . (2017). Gerakan Literasi Nasional, Materi Pendukung Literasi Baca Tulis. Jakarta: Kemendikbud. Kubota, R., \& Lin, A. (2009). Race, culture, and identities in second language education: Exploring critically engaged practice. Routledge.

Lankford, H., Loeb, S., \& Wyckoff, J. (2002). Teacher sorting and the plight of urban schools: A descriptive analysis. Educational Evaluation and Policy Analysis, 24(1), 37-62.

Lee, K. R., \& Oxford, R. (2008). Understanding EFL learners' strategy use and strategy awareness. Asian EFL Journal, 10 (1), 7-32

Marton, F. \& Booth, S. (1997). Learning and awareness. Mahwah, NJ: Lawrence Elbraum.

Motha, S. (2006). Racializing ESOL teacher identities in U.S. K12 public schools. TESOL Quarterly, 40(3), 495-518.

Muijs, D. (2011). Doing quantitative research in education with SPSS. London: Sage Publication Ltd.

Noor et al. The effectiveness of multicultural approach in writing achievement of indonesian language among islamic elementary school students. Jurnal Cakrawala Pendidikan, [S.1.], p. 366-376, june 2019. ISSN 2442-8620. Available at: https://journal.uny.ac.id/index.php/cp/article/view/23440.

Noor, N. M. (2011). Reading habits and preferences of EFL postgraduates: A case study. Indonesian Journal of Applied Linguistics, 1(1), 1-8. https://doi.org/10.17509/ijal.v1i1.95

OECD. (2018). Programme for International Student Assessment (PISA). Diakses melalui http://www.oecd.org/pisa/PISA-2018-Indonesia .pdf pada tanggal 10 Desember 2020.

OECD. (2019). PISA 2018 results. What students know and can do (Vol. 1). https://www.oecd.org/

Oxford, R. L. (1990). Language learning strategies: what ever teacher should know. New York:

Newbury House Publishers.

Oxford, R. (2001). Integrated skills in the ESL/EFL Classroom. ERIC Digest.

Plakans, L., \& Gebril, A. (2013). Using multiple texts in an integrated writing assessment: Source text use as a predictor of score. Journal of Second Language Writing, 22 (3), 217-230. https://doi.org/10.1016/J.JSLW.2013.02.003

Plakans, L., \& Gebril, A. (2017). Exploring the relationship of organization and connection with scores in integrated writing assessment. Assessing Writing, 31, 98-112. https://doi.org/10.1016/j.asw.2016.08.005

Purba, A. S., Malihah, E., \& Hufad, A. (2019). The implementation of multicultural education in senior high schools in Medan. BIRCI-Journal, 2(3), 226-233. https://doi.org/10.33258/birci.v2i3.411

Priyatni, E., T. \& Wahono, A., S. (2012). Model penyusunan bahan ajar membaca berbasis pendidikan multikultural dan e-learning. Jurnal ilmiah bahasa, sastra dan pengajarannya LITERA. [Versi elektronik]. Volume 11, Nomor 1, April.

Reynolds, C.R, Livingstone, R.B \& Wilson, V. (2010). Measurement and assessment in education. New Jersey: Pearson Education.

Sarraj, H., Bene, Konabe., Li Jiaqi \& Burley, H. (2015). Raising cultural awareness of fifth-grade students through multicultural education: an action research study. [Versi elektronik]. Multicultural education, Vol. 22, No.2, p39-45. 7p.

Shapira, N., Kali, Y., Kupermintz, H., \& Dolev, N. (2020).Teachers Foster Intergroup Empathy. International Journal of Multicultural Education, 22(3), 1-23. doi:http://dx.doi.org/10.18251/ijme.v22i3.2225

Shannon-Baker, P. (2018). A multicultural education praxis: Integrating past and present, living theories, and practice. International Journal of Multicultural Education, 20(1), 48- 66. https://doi.org/10.18251/ijme.v20i1.1518

Singh, B. R. (1984). Multicultural education: A study of the impact of the CNAA on a B.Ed. Degree. Educational Studies, 10, 227-236. https://doi.org/10.1080/0305569840100303 
Siswandari. (2014). Pembelajaran bahasa dan sastra Indonesia di sekolah sebagai media perekat multikulturalisme. Dalam Wiyatmi, dkk (Editor), Bahasa dan sastra dalam ekologi dan multikulturalisme (pp. 121-133). Yogyakarta: Interlude - Fakultas Bahasa \& Sastra UNY.

Siswati dan Widiyanti. (2009). Fenomena bullying di Sekolah Dasar Negeri di Semarang : Sebuah Studi Deskriptif. Jurnal UNDIP Vol 5 No 2, Oktober 2009. Semarang : Fakultas Psikologi UNDIP.

Siswoyo, Dwi. Pandangan bung karno tentang pancasila dan pendidikan. Jurnal Cakrawala Pendidikan, [S.1.], n.1, may 2013. ISSN 2442-8620. doi:https://doi.org/10.21831/cp.v5i1.1264.

Soraya, R. (2010). Pengaruh penerapan strategi pembelajaran (PBMP + TPS dan Inkuiri) dan jenis kelamin terhadap hasil belajar dan keterampilan metakognitif siswa SD. Disertasi tidak diterbitkan: Malang, Universitas Negeri Malang.

Sunggingwati, D., \& Nguyen, H. T. M. (2013). Teachers' questioning in reading lessons: A case study in Indonesia. Electronic Journal of Foreign Language Teaching, 10(1), 80-95. https://eflt.nus.edu.sg/v10n12013/sunggingwati.pdf

Suzuki, B. H. (1979). Multicultural education: What's it all about? Integrated Education, 17, 47-48. https://doi.org/10.1080/0020486790170109

Tompkins, G., E. \& Hoskisson, K. (1995). Language arts: content and teaching strategies. Maxwell Macmillan Canada. University Michigan.

Turgut, Yildiz \& Tuncer, Ufuk. (2011). Literacy development in multicultural settings with digital duallanguage books. Journal of language \& linguistics studies. [Versi elektronik]. Vol. 7 Issue 2, p117-143.27p.

Vittrup, Brigitte. (2016). Early childhood teachers' approaches to multicultural education \& perceived barriers to disseminating anti-bias messages. Multicultural education journal. [Versi elektronik]. Vol. 23 Issue 3/4, p37-41. 5p.

Watson, I. (2010). Multiculturalism in South Korea: A critical assessment. Journal of Contemporary Asia, 40(2),337-346.

Weick, K. (1995). Sensemaking in organizations. SAGE.

X. Zhu, G.Y. Li, C.M. Cheong, G. Yu and X. Liao. (2020). Reading and Writing, Article 0123456789, 10.1007/s11145-020-10065-X.

Yang, H. C. (2014). Toward a model of strategies and summary writing performance. Language Assessment Quarterly, 403-431 https://doi.org/10.1080/15434303.2014.957381.

Yang, H. C., \& Plakans, L. (2012). Second language writers' strategy use and performance on an integrated reading-listening-riting ask. TESOL Quarterly, 46(1), 80-103 https://doi.org/10.1002/tesq.6

Yilmaz, F. (2016). Multiculturalism and multicultural education: A case study of teacher candidates' perceptions. Cogent Education, 3, 1 - 13., https://doi.org/10.1080/2331186X.2016.11723

Zins, J. E., Bloodworth, M. R., Weissberg, R. P., \& Walberg, H. J. (2004). The scientific base linking social and emotional learning to school success. In J. E. Zins (Ed.), Building Academic Success on Social and Emotional Learning: What Does the Research Say(pp. 3-22).New York, NY: Teachers College Press.

Zuchdi, Darmiati, Kun Prasetya, Zuhdan \& Siasah, Muhsinatun. (2012). Panduan implementasi pendidikan karakter terintegrasi dalam pembelajaran dan pengembangan kultur sekolah. Yogyakarta: UNY Press.

Zhu et al., 2020 Secondary school students' discourse synthesis performance on Chinese (L1) and English (L2) integrated writing assessments.

Zhu, X., Li, G. Y., Cheong, C. M., Yu, G., \& Liao, X. (2020). Secondary school students' discourse syn thesis performance on Chinese (L1) and English (L2) integrated writing assessments. Reading and Writing. , Article 0123456789. https://doi.org/10.1007/s11145-020-10065-x. 